DOI 10.18551/rjoas.2019-12.19

\title{
LABOUR AND POVERTY FOR THE GREEK AGRICULTURAL POPULATION, BEFORE AND DURING THE ECONOMIC CRISIS
}

\author{
Dr. Ioannides Alexis ${ }^{\star}$, Associate Professor \\ Department of Social Policy, Democritus University of Thrace, Komotini, Greece \\ ORCID: 0000-0002-3924-1771 \\ Dr. Oxouzi Eleni, Associate Staff \\ Hellenic Open University, Thessaloniki, Greece \\ ORCID: 0000-0003-4187-4196 \\ *E-mail: aioann@sp.duth.gr
}

\begin{abstract}
Agricultural population of Greece has been in the center of a political and economical turmoil for many years. Yet, it has not been investigated enough as to its employment and living conditions. This article is one of the first attempts to describe the demographical characteristics of the agricultural population in Greece. It then proceeds to the exploration of employment conditions of this population compared to the non-agricultural population of Greece. Finally, living conditions and poverty of agricultural population are estimated for specific subgroups, before and after the initiation of the current economic crisis, drawing interesting results. The analysis shows that agricultural population still constitutes a great part of Greek population, although diminished by the crisis. It contains not only farmers but, to a great extend, employees working in non agricultural sectors and occupations. The most interesting and striking of the results are related to poverty and living conditions, which prove to be much worst for agricultural compared to the rest of the Greek population. On average poverty rates are twice as much as the rest of the population and the early years of the crisis barely changed this image. The employees that work outside the agricultural sector are in better shape in terms of poverty, something that reveals and justifies the long term tendency of the agricultural population to abandon agricultural life.
\end{abstract}

\section{KEY WORDS}

Labour, poverty rate, agricultural population, Greece, economic crisis, demographics.

Agricultural population in Greece, namely the population associated with agriculture, is a part of the Greek population that has played an important role in the country's contemporary economic and social development. Despite the many changes and downsizing it has undergone in recent decades, it is still an important and dynamic part of the Greek society. However, the study of its social and economic characteristics is quite limited, with relevant surveys not focusing on the specific study of this population, with the only exception of a thorough investigation by Papatheodorou (2000).

This research attempts to cover this serious gap in the literature by examining specifically the working and living conditions of agricultural population, compared to the rest of the country's population. To make this possible, we initially determine the notion of agricultural population and how this notion can be accessed by the available statistical data. Thereby, EU-SILC data are used for the first time to describe the agricultural population and separate it from the rest of the country's population. Once this separation is done, we study its demographic characteristics and conclusions are drawn about its demographic situation at the start of the economic crisis.

In addition to demographic characteristics, the study describes in detail the employment conditions of this population, both before the beginning of the last severe economic crisis and during its early years. It showcases the moving of agricultural population 
to salaried occupations outside the agricultural sector, which had largely advanced before the crisis, but appears to be limited by its arrival.

Perhaps the most important part of this research involves the examination of living conditions and poverty faced by the agricultural population. The findings are remarkably alarming, revealing the very large poverty rate and the low income that define this population. Living conditions and poverty are examined from several different aspects, providing a detailed picture of the economic life of the families of the agricultural population.

The structure of this article is as follows: the next chapter presents the basic methodological issues and an overview of relevant bibliography. The third chapter presents the main demographic and employment characteristics of the agricultural population. The fourth chapter elaborates on the living conditions and calculates poverty rates for various subcategories of this population and finally the fifth chapter draws our final conclusions.

\section{METHODOLOGICAL ISSUES}

Definition of Agricultural Population. This survey aims to study the working and living conditions as well as poverty in the agricultural population of Greece. The concept of "agricultural population" should initially be separated from that of "rural population". The latter in Greece, according to the 2001 census, is defined as the population living in settlements of less than 2,000 inhabitants, regardless of the professions exercised (Daoutopoulos, Kazakopoulos and Kousi, 2005). This definition stems from the concept of rural areas which includes sparsely populated areas and is not related to the employment of the residents, neither does it relate to a specific land use or a specific economic sector (OECD, 1993; 2006).

In regard to the agricultural population there is not, until today, a distinct and uniform interpretation of the concept, both globally and also between Member States of the European Union. According to the Food and Agriculture Organization of the United Nations, the agricultural population is defined as the population (economically active or not) depending for their livelihood on agriculture, hunting, forestry or fishing (FAO, 2010). In accordance also with the definition of the Organization for Economic Cooperation and Development (OECD), a household is considered agricultural where at least one member of the household operates a farm or when the head of the household, the referred person or the main economical contributor is economically active in agriculture (OECD, 1984). According to Eurostat's methodology manual (Eurostat, 1995), in a broad sense definition, agricultural households are those that acquire a part of their income from independent employment in agriculture. This income can be derived from the head of the household or any other family member (Central Statistics Office, 2008). In a narrow sense, as agricultural households are defined those whose income from independent agricultural activity is the main source of the total income of the referred household.

In the relevant literature such an analytical description and separation of agricultural population from the rest of Greek population has not yet been realised with the help of this methodology.

In this particular investigation, we have defined as an agricultural household (and by extension, agricultural population) the household of which at least one member is primarily employed in agriculture, namely we have chosen the wider definition. This choice was based, apart from the above reasons, on the structure, the needs and the characteristics of Greek holdings.

In Greece, $99.9 \%$ of the holdings are of family form (personal holdings), $76.1 \%$ are smaller than 50 acres and multi-segmented ${ }^{1}$. The above structural characteristics of Greek farms "force" family members, regardless of the professional relationship they have with agriculture, to work seasonally or permanently on the farm in order to reduce the cost of labour which almost always is a decisive factor for achieving profits or not. The seasonal or

\footnotetext{
1 According to the Ministry of Agricultural Development and Food, Special Secretariat for community resources and infrastructures - Programme for rural development in Greece 2007-2013 -eleventh edition- March 2012.
} 
permanent employment of the members ensures the "survival" of Greek farms and so those members of agricultural households, regardless of the economic/professional relationship they have with agriculture, are closely connected with agricultural work. For these reasons, in this survey we have incorporated, in the notion of agricultural population, every household in which at least one member is by main occupation a crop farmer, a stockbreeder or a fisherman.

Measuring Poverty. Poverty as a social phenomenon has been studied intensively and in a multi-faceted way. For its study, different definitions have been used. Each of these definitions reflects a different approach to this complex social phenomenon, influenced by historical evolution, political and social processes and the evolution of ideological confrontation. Consequently, different approaches have been used, such as "subjective" and "objective" poverty, absolute and relative poverty, while different opinions have also been expressed on the level of poverty line ${ }^{2}$.

"Poverty" is defined as the condition of a person the equivalent disposable income of which is less than a minimum value of income, called "poverty line". This value is typically set equal to $60 \%$ of the medium equivalent disposable income of household members of a country and this definition will be used in this research, for the sake of comparability with similar studies conducted internationally.

The equivalent disposable personal income of each household member occurs when the total disposable income of the household is divided by an equivalence scale for each household. The disposable income of each household member includes the income from work and from fortune, social benefits and pensions, as well as cash transfers from other households after the deduction of taxes and social security contributions.

The equivalence scale used for households, weights the first adult equal to 1 , the second adult and members above 14 years of age with 0,5 and with 0,3 every child bellow 13 years of $\mathrm{age}^{3}$. It is obvious that this calculation takes into account the economies of scale arising from cohabitation. Also, every person of the household is supposed to possess the same equivalent disposable income, therefore all household members enjoy the same living standard. Therefore, the equivalent disposable personal income is not a real income but an approach to the living standard of each individual.

After we have defined and calculated the equivalent disposable personal income, we can then compute the poverty rate (alternatively called poverty risk) of a population. As poverty rate we define the proportion of the population below the poverty line compared to the whole population. The poverty line, as mentioned earlier, is the equivalent income that is equal to $60 \%$ of the median disposable equivalent income of the residents of a country. According to Papatheodorou et al. (2008), this limit is relatively arbitrary and without theoretical foundation. However, it is this that has prevailed in relevant literature and therefore it is what will be used in this research.

An additional indicator that will be used is the contribution to poverty, which is defined as the share of the poor that each individual group contains, as to the total of the poor of this population.

The risk of poverty and the contribution to poverty can be measured both before and after the pensions and other social transfers. As social transfers, apart from pensions, we also consider social benefits given to vulnerable population groups, such as income support for the inhabitants of mountainous and less-favoured areas, unemployment allowances, as well as long-term unemployment, sickness, disability and family allowances. The reason why this special calculation is performed is that it allows an estimation of the influence that pensions and other social transfers have in reducing poverty risk. This calculation has made possible the classification of European countries into models of welfare state. This taxonomy has been initially proposed by Esping-Andersen (1990), who classified countries according to

\footnotetext{
${ }^{2}$ For a detailed presentation of the subject see also Atkinson (1983), Townsend (2004), Papatheodorou (2008), Chossudovsky (1998).

${ }^{3}$ Based on the modified OECD scale Eurostat uses. Atkinson, Rainwater and Smeeding (1995) provide a comprehensive overview of various equivalence scales that have occasionally been used. See also Hagenaars, De Vos and Zaidi (1994).
} 
their welfare system to three groups: a) the social democratic, b) the corporatist and c) the liberal. According to Ferrera (1996) there is a fourth group of countries, the South European,

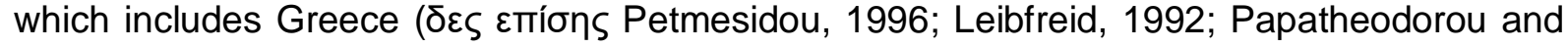
Petmezidou, 2004).

Data Sources. In this research, we use micro-data of income and living condition survey (EUSILC) ${ }^{4}$, which is an annual sample survey conducted since 2003; it provides data on income, living conditions and social exclusion in most European countries. The sample size is considered adequate for a representative description of each country's population indicatively, for Greece in the year 2009 it is over 18,000 people. The data used in this research covers the years 2009, 2010 and 2011 and it concerns the incomes of each previous year, i.e. the years 2008, 2009 and 2010 respectively.

It should be noted that this data covers a period just before the start of the economic crisis in Greece and until its first two years. Given that so far there has not been a detailed investigation of the situation regarding the poverty of workers in agriculture and more generally of the agricultural population in Greece, it is important that the first year covered by the survey is prior to the emergence of the crisis. This allows us to capture an image of the income situation of the agricultural population, as it had been shaped by the developments in recent decades. The two subsequent years covered by the survey (2010 and 2011), which are the first years of the intensification of the crisis, allow conclusions to be made about the direction and the developments created by the economic crisis in Greece regarding the situation of the agricultural population.

\section{DEMOGRAPHIC AND EMPLOYMENT CONDITIONS OF THE AGRICULTURAL POPULATION}

Definition and Basic Demographic Characteristics of the Agricultural Population. We will now proceed to the determination of agricultural population in Greece, for the first time according to our knowledge, based on the broad definition that was chosen and with the help of the statistical data of EU-SILC. As shown in the results of this process (table 1), the agricultural population before the crisis (2009) was more than $20 \%$ of the total Greek population. Thus, despite the long-term crisis of the agricultural sector in Greece, a large part of the inhabitants of the country still has a direct association with incomes from agriculture. It should be noted that, as will be shown, it is not that the entire agricultural population is exclusively employed in agricultural activity. A large portion of this population exercises professions outside the primary section, as does the rest of the non-agricultural population. For this reason, an important part of Greek wage-labourers belongs to the agricultural population and will be studied in detail.

Equally impressive is the reduction of agricultural population during the first two years of the crisis, showing a fall of approximately $13.0 \%$, with a corresponding increase in nonagricultural population.

Table 1 - Size of agricultural population, 2009-2011

\begin{tabular}{|c|c|c|c|c|c|c|}
\hline \multirow{2}{*}{$\mathrm{n} / \mathrm{n}$} & \multicolumn{2}{|c|}{2009} & \multicolumn{2}{c|}{2010} & \multicolumn{2}{c|}{2011} \\
\cline { 2 - 6 } & $\mathrm{N}$ & Share & $\mathrm{N}$ & Share & $\mathrm{N}$ & Share \\
\hline Non agricultural population & 8652786 & $79,3 \%$ & 8798554 & $80,3 \%$ & 9028598 & $82,1 \%$ \\
\hline Agricultural population & 2257270 & $20,7 \%$ & 2152782 & $19,7 \%$ & 1962614 & $17,9 \%$ \\
\hline Total & 10910056 & $100,0 \%$ & 10951336 & $100,0 \%$ & 10991212 & $100,0 \%$ \\
\hline
\end{tabular}

Source: Own estimations using Eurostat's EU-SILC microdata.

It seems that the advent of the crisis in Greece not only reversed but accelerated the long-term reduction course of the agricultural population and almost 300,000 people abandoned it within two years, probably permanently.

\footnotetext{
${ }^{4}$ EU-SILC micro-data were made accessible to authors due to their cooperation with the Department of Social Policy of the Democritus University of Thrace.
} 
We will now examine some basic demographic characteristics of the agricultural population. Gender data is shown in table 2. The slight predominance of men before the crisis is fully balanced and so in 2011 there is absolute equality between men and women in the agricultural population. If we assume that the demographic composition changes slowly, it can be argued that more men than women have abandoned the agricultural population after at the beginning of the crisis.

Table 2 - Sex composition of agricultural population, 2009, 2011

\begin{tabular}{|c|c|c|c|c|c|c|}
\hline \multirow{2}{*}{$\mathrm{n} / \mathrm{n}$} & \multicolumn{3}{|c|}{2009} & & \multicolumn{3}{c|}{2011} \\
\cline { 2 - 7 } & $\begin{array}{c}\text { Agricultural } \\
\text { population }\end{array}$ & $\begin{array}{c}\text { Non agricultural } \\
\text { population }\end{array}$ & Total & $\begin{array}{c}\text { Agricultural } \\
\text { population }\end{array}$ & $\begin{array}{c}\text { Non agricultural } \\
\text { population }\end{array}$ & Total \\
\hline Males & $50,9 \%$ & $48,8 \%$ & $49,2 \%$ & $50,0 \%$ & $49,1 \%$ & $49,3 \%$ \\
\hline Females & $49,1 \%$ & $51,2 \%$ & $50,8 \%$ & $50,0 \%$ & $50,9 \%$ & $50,7 \%$ \\
\hline
\end{tabular}

Source: Own estimations using Eurostat's EU-SILC microdata.

Regarding age, the comparison of the agricultural population with the total country population is of particular interest (table 3). In those aged under 15 years there is a significantly smaller proportion in agricultural population than in the rest of the population. This difference persists for productive ages until 45 years old and only over those ages is the situation balanced. The image is reversed in full for persons over 65 years old, where the rate of agricultural population is almost double to that of the entire population. This image confirms the conclusion about the aging of agricultural population, with the long-term tendency exacerbating this phenomenon.

Table 3 - Age cohorts, 2009, 2011

\begin{tabular}{|c|c|c|c|c|c|c|c|c|}
\hline \multirow{2}{*}{$\mathrm{n} / \mathrm{n}$} & \multicolumn{4}{|c|}{2009} & \multicolumn{4}{c|}{2011} \\
\cline { 2 - 8 } & Agricultural population & \multicolumn{2}{|c|}{ Total population } & Agricultural population & \multicolumn{2}{c|}{ Total population } \\
\hline Age & $\mathrm{N}$ & Percent. & $\mathrm{N}$ & Percent. & $\mathrm{N}$ & Percent. & $\mathrm{N}$ & Percent. \\
\hline $0-6$ & 91210 & $4,0 \%$ & 794479 & $7,3 \%$ & 69028 & $3,5 \%$ & 793314 & $7,2 \%$ \\
\hline $7-15$ & 141460 & $6,3 \%$ & 902960 & $8,3 \%$ & 127230 & $6,5 \%$ & 925672 & $8,4 \%$ \\
\hline $16-24$ & 155072 & $6,9 \%$ & 1061721 & $9,7 \%$ & 135399 & $6,9 \%$ & 1015973 & $9,2 \%$ \\
\hline $25-34$ & 259071 & $11,5 \%$ & 1624914 & $14,9 \%$ & 186117 & $9,5 \%$ & 1568060 & $14,3 \%$ \\
\hline $35-44$ & 273221 & $12,1 \%$ & 1690819 & $15,5 \%$ & 235452 & $12,0 \%$ & 1723306 & $15,7 \%$ \\
\hline $45-54$ & 275401 & $12,2 \%$ & 1495616 & $13,7 \%$ & 240806 & $12,3 \%$ & 1529718 & $13,9 \%$ \\
\hline $55-64$ & 304195 & $13,5 \%$ & 1319524 & $12,1 \%$ & 269605 & $13,7 \%$ & 1351923 & $12,3 \%$ \\
\hline$>65$ & 757641 & $33,6 \%$ & 2020023 & $18,5 \%$ & 698977 & $35,6 \%$ & 2083246 & $19,0 \%$ \\
\hline Total & 2257271 & $100 \%$ & 10910056 & $100 \%$ & 1962614 & $100 \%$ & 10991212 & $100 \%$ \\
\hline
\end{tabular}

Source: Own estimations using Eurostat's EU-SILC microdata.

Between the two years before and after the crisis, there is a significant reduction in the 25-34 age group of agricultural population, which is one of the most dynamic, indicating that a part of young people that had remained is now leaving Greek agriculture with a faster pace. Correspondingly we observe an increase in percentage of the population over $65 \%$, certainly representing the reduced mobility of retired individuals.

Table 4 - Education level of agricultural population, 2009

\begin{tabular}{|c|c|c|c|c|}
\hline \multirow{2}{*}{$\mathrm{n} / \mathrm{n}$} & \multicolumn{2}{|c|}{ Agricultural population } & \multicolumn{2}{c|}{ Non agricultural population } \\
\cline { 2 - 5 } & N. of persons & Percentage & N. of persons & Percentage \\
\hline No education & 117753 & $5,8 \%$ & 75361 & $1,1 \%$ \\
\hline Pre primary education & 247093 & $12,3 \%$ & 222371 & $3,1 \%$ \\
\hline Primary education & 893541 & $44,3 \%$ & 1411373 & $19,8 \%$ \\
\hline Lower secondary education & 259714 & $12,9 \%$ & 766415 & $10,8 \%$ \\
\hline Secondary education & 358417 & $17,8 \%$ & 2492066 & $35,0 \%$ \\
\hline Post-secondary education & 35268 & $1,7 \%$ & 392284 & $5,5 \%$ \\
\hline Tertiary education & 103796 & $5,1 \%$ & 1764838 & $24,8 \%$ \\
\hline
\end{tabular}

Source: Own estimations using Eurostat's EU-SILC microdata. 
With regard to the level of education (table 4), we will only present the year before the crisis (2009), since the differences are not significant compared to 2011. We observe that the majority of the agricultural population are graduates of primary schools, while the nonagricultural one are graduates of secondary education. The percentage of population that has not completed any grade of education is also significant. In addition, only $5 \%$ of the agricultural population has university education, as opposed to approximately $25 \%$ of the non-agricultural population.

This image indicates a weak association of the agricultural population with education, however an important affecting factor is age composition, since, as we have seen, the agricultural population is dominated by elderly people, which generally have a low level of education.

Employment Conditions of Greek Agricultural Population. Subsequently, we will examine the basic employment characteristics and working conditions of the agricultural population in Greece, compared with those of non-agricultural population (table 5). A significant proportion of the agricultural population consists of full-time and part-time wagelabourers. Their rate is markedly smaller than that of the rest of the population, though it is not at all insignificant. Specifically, before the crisis they constituted the $14.4 \%$ of the total agricultural population over 15 years old, however with the pensioners and other inactive population put aside, it reaches $30 \%$ of the economically active agricultural population. This indicates that a large proportion of the agricultural population had, already years ago, turned to other professions outside of the agricultural section (as wage labour in agriculture is very limited) in order to supplement the agricultural income and to ensure better living conditions.

A second observation is that the percentage of the self-employed is significantly greater than that of the non-agricultural population. As a result, nearly half of the selfemployed without employees in Greece belong to the agricultural population. This was expected, since a large portion of farmers in Greece are owners of the land they work on and therefore belong to the category of self-employed.

Table 5 - Status in employment, 2009, 2011

\begin{tabular}{|c|c|c|c|c|c|c|c|c|}
\hline $\begin{array}{c}\text { Persons }>15 \text { yrs } \\
\text { of age }\end{array}$ & \multicolumn{3}{|c|}{2009} & \multicolumn{4}{c|}{2011} \\
\hline $\begin{array}{c}\text { Employment } \\
\text { status }\end{array}$ & \multicolumn{2}{|c|}{$\begin{array}{c}\text { Agricultural } \\
\text { population }\end{array}$} & \multicolumn{2}{|c|}{$\begin{array}{c}\text { Non agricultural } \\
\text { population }\end{array}$} & \multicolumn{2}{c|}{$\begin{array}{c}\text { Agricultural } \\
\text { population }\end{array}$} & \multicolumn{2}{c|}{$\begin{array}{c}\text { Non agricultural } \\
\text { population }\end{array}$} \\
\cline { 2 - 10 } & $\mathrm{N}$ & Percent. & $\mathrm{N}$ & Percent. & $\mathrm{N}$ & Percent. & $\mathrm{N}$ & Percent. \\
\hline $\begin{array}{c}\text { Employee - Full } \\
\text { time }\end{array}$ & 260645 & $12,9 \%$ & 2492361 & $35,0 \%$ & 153768 & $8,7 \%$ & 2043852 & $27,8 \%$ \\
\hline $\begin{array}{c}\text { Employee - Part } \\
\text { time }\end{array}$ & 29727 & $1,5 \%$ & 193073 & $2,7 \%$ & 17950 & $1,0 \%$ & 220431 & $3,0 \%$ \\
\hline $\begin{array}{c}\text { Self employed } \\
\text { without } \\
\text { employees }\end{array}$ & 450366 & $22,3 \%$ & 529074 & $7,4 \%$ & 349815 & $19,9 \%$ & 506657 & $6,9 \%$ \\
\hline $\begin{array}{c}\text { Self employed } \\
\text { with employees }\end{array}$ & 58109 & $2,9 \%$ & 259680 & $3,6 \%$ & 36290 & $2,1 \%$ & 180452 & $2,5 \%$ \\
\hline $\begin{array}{c}\text { Self employed }- \\
\text { Part time }\end{array}$ & 75291 & $3,7 \%$ & 86204 & $1,2 \%$ & 65217 & $3,7 \%$ & 69029 & $0,9 \%$ \\
\hline Unemployed & 74679 & $3,7 \%$ & 424236 & $6,0 \%$ & 161564 & $9,2 \%$ & 1042208 & $14,2 \%$ \\
\hline Pupil, student & 72078 & $3,6 \%$ & 614418 & $8,6 \%$ & 60437 & $3,4 \%$ & 601418 & $8,2 \%$ \\
\hline In retirement & 775737 & $38,5 \%$ & 1296515 & $18,2 \%$ & 740001 & $42,0 \%$ & 1545416 & $21,0 \%$ \\
\hline Domestic tasks & 148225 & $7,4 \%$ & 1047007 & $14,7 \%$ & 120629 & $6,8 \%$ & 1005077 & $13,7 \%$ \\
\hline Other inactive & 70725 & $3,5 \%$ & 182137 & $2,6 \%$ & 56510 & $3,2 \%$ & 136889 & $1,9 \%$ \\
\hline Total & 2015582 & $100,0 \%$ & 7124705 & $100,0 \%$ & 1762181 & $100,0 \%$ & 7351429 & $100,0 \%$ \\
\hline
\end{tabular}

Source: Own estimations using Eurostat's EU-SILC microdata.

The unemployed constituted only a small part of the agricultural population before the crisis, while the category that stands out is that of farmers in retirement, which occupies nearly $40 \%$ of farmers, with a more than double percentage of pensioners, compared to the rest of the country's retired. The proportion of individuals that are exclusively fulfilling domestic tasks is considerably smaller; this finding reveals the multifaceted role of women in 
agricultural life. Also small is the share of pupils and students, as a result of the small participation of the respective ages in the agricultural population.

The first two years of the crisis seems to have a significant impact on the composition of the agricultural population. A decrease in the number of people aged over 15 years is observed, surpassing 250,000 people, while there is a corresponding increase in nonagricultural population, indicating the displacement of population that was previously mentioned. At the same time we observe a large increase in the share of the retired, as well as in the rest of the population. The decrease observed in the self-employed (mostly farmers) is considerably smaller than the decrease in full-time or part-time employees. This shows that the agricultural population has lost more of the jobs outside the agricultural sector, in comparison to those of the agricultural sector, namely it is separated, to some extent, from non-agricultural activity. This may also be a result of the withdrawal from agricultural population of individuals who already had wage labour.

The increase in unemployment of the agricultural population is also significant and consistent in tension with the general increase in unemployment. Therefore, the agricultural population was equally affected by the increase in unemployment; however its exposure to this social risk remains significantly lower than that of the other inhabitants of the country.

In conclusion, it can be argued that over the years the agricultural population has gradually withdrawed from the cultivation of land as a sole source of income and spread to other professions. At the same time, an important part of this population abandons agricultural work completely and leaves the agricultural population. This phenomenon was intensified by the crisis, which has however also withdrawed agricultural population from nonagricultural occupations.

Table 6 - Status in employment by sex, 2009, 2011

\begin{tabular}{|c|c|c|c|c|c|c|c|c|}
\hline $\mathrm{n} / \mathrm{n}$ & \multicolumn{4}{|c|}{2009} & \multicolumn{4}{|c|}{2011} \\
\hline $\begin{array}{c}\text { Persons }>15 \text { yrs of } \\
\text { age }\end{array}$ & \multicolumn{2}{|c|}{$\begin{array}{l}\text { Agricultural } \\
\text { population }\end{array}$} & \multicolumn{2}{|c|}{$\begin{array}{c}\text { Non agricultural } \\
\text { population }\end{array}$} & \multicolumn{2}{|c|}{$\begin{array}{l}\text { Agricultural } \\
\text { population }\end{array}$} & \multicolumn{2}{|c|}{$\begin{array}{c}\text { Non agricultural } \\
\text { population }\end{array}$} \\
\hline Employment status & Males & Females & Males & Females & Males & Females & Males & Females \\
\hline \multicolumn{9}{|c|}{ Percentage of relevant population } \\
\hline Employee - Full time & $17,9 \%$ & $7,9 \%$ & $41,4 \%$ & $29,0 \%$ & $11,9 \%$ & $5,6 \%$ & $32,5 \%$ & $23,3 \%$ \\
\hline $\begin{array}{c}\text { Employee - Part } \\
\text { time }\end{array}$ & $0,9 \%$ & $2,0 \%$ & $1,5 \%$ & $3,8 \%$ & $0,9 \%$ & $1,1 \%$ & $1,7 \%$ & $4,2 \%$ \\
\hline $\begin{array}{c}\text { Self employed } \\
\text { without employees }\end{array}$ & $27,9 \%$ & $16,7 \%$ & $10,2 \%$ & $4,9 \%$ & $25,4 \%$ & $14,4 \%$ & $10,2 \%$ & $3,7 \%$ \\
\hline $\begin{array}{l}\text { Self employed with } \\
\text { employees }\end{array}$ & $4,4 \%$ & $1,3 \%$ & $6,1 \%$ & $1,4 \%$ & $3,3 \%$ & $0,9 \%$ & $4,0 \%$ & $1,0 \%$ \\
\hline $\begin{array}{c}\text { Self employed - Part } \\
\text { time }\end{array}$ & $2,0 \%$ & $5,5 \%$ & $0,8 \%$ & $1,6 \%$ & $1,8 \%$ & $5,5 \%$ & $0,7 \%$ & $1,1 \%$ \\
\hline Unemployed & $3,8 \%$ & $3,6 \%$ & $5,5 \%$ & $6,4 \%$ & $9,7 \%$ & $8,6 \%$ & $15,5 \%$ & $12,9 \%$ \\
\hline Pupil, student & $3,3 \%$ & $3,9 \%$ & $9,3 \%$ & $8,0 \%$ & $3,4 \%$ & $3,4 \%$ & $8,0 \%$ & $8,3 \%$ \\
\hline In retirement & $36,6 \%$ & $40,4 \%$ & $22,4 \%$ & $14,3 \%$ & $39,9 \%$ & $44,0 \%$ & $24,8 \%$ & $17,4 \%$ \\
\hline Domestic tasks & $0,0 \%$ & $14,9 \%$ & $0,0 \%$ & $28,3 \%$ & $0,0 \%$ & $13,5 \%$ & $0,0 \%$ & $26,7 \%$ \\
\hline Other inactive & $3,2 \%$ & $3,8 \%$ & $2,9 \%$ & $2,2 \%$ & $3,6 \%$ & $2,8 \%$ & $2,4 \%$ & $1,3 \%$ \\
\hline
\end{tabular}

Source: Own estimations using Eurostat's EU-SILC microdata.

The examination of the employment situation in relation to gender is also particularly interesting. We observe that in the agricultural population before the crisis, women have proportionately less participation in wage labour, but their involvement in self-employment (primarily related to agricultural work) is considerably high and comparable with that of men. They also have a high percentage of part-time self-employment, surpassing that of men. Unemployment rates of women before the crisis were slightly better than that of men, the opposite of what was happening in the non-agricultural population. In pensioners, women outnumbered men in the agricultural population, while in the non-agricultural population their numbers remained well below those of men. Of particular interest is the proportion of selfemployed women with part-time jobs, which is the highest for this type of employment relationship and reveals another peculiarity of the Greek countryside, where agricultural work 
can be exercised partially. Finally, the percentage of women's exclusively domestic work is much smaller in agricultural population than in the rest, showing the difficulty of surviving in the countryside when there is an exclusive preoccupation with domestic work.

After the start of the crisis (2011), the percentage of unemployed women of the agricultural population grows significantly but much less than that of men, following a path corresponding with the unemployment percentage of non-agricultural population. This is because the reduction of wage labour, although important, is smaller in women than in men in the agricultural population. Unlike wage labour, self-employment presents a slight decrease among the agricultural population, nearly equivalent in men and women. Based on these data we can say that the phenomenon of the withdrawal of the agricultural population from non-agricultural activities is more pronounced in men than in women.

The long-lasting displacement of the agricultural population to other non-agricultural occupations, but also the reversal of this tendency by the crisis is illustrated in table 7, which presents the occupations of agricultural population.

Table 7 - Occupations of agricultural population, 2009, 2011

\begin{tabular}{|c|c|c|c|c|}
\hline $\mathrm{n} / \mathrm{n}$ & \multicolumn{2}{|c|}{2009} & \multicolumn{2}{c|}{2011} \\
\hline Employees and self-employed & $\begin{array}{c}\text { Agricultural } \\
\text { population }\end{array}$ & $\begin{array}{c}\text { Non agricultural } \\
\text { population }\end{array}$ & $\begin{array}{c}\text { Agricultural } \\
\text { population }\end{array}$ & $\begin{array}{c}\text { Non agricultural } \\
\text { population }\end{array}$ \\
\hline Occupation & \multicolumn{3}{|c|}{ Percentage of relevant population } \\
\hline $\begin{array}{c}\text { Legislators, senior officials and } \\
\text { managers }\end{array}$ & $4,9 \%$ & $10,1 \%$ & $5,2 \%$ & $12,1 \%$ \\
\hline Professionals & $3,5 \%$ & $20,3 \%$ & $1,6 \%$ & $20,8 \%$ \\
\hline $\begin{array}{c}\text { Technicians and associate } \\
\text { professionals }\end{array}$ & $1,7 \%$ & $9,7 \%$ & $1,7 \%$ & $10,3 \%$ \\
\hline Clerks & $3,9 \%$ & $13,8 \%$ & $3,6 \%$ & $14,9 \%$ \\
\hline $\begin{array}{c}\text { Service workers and shop and } \\
\text { market sales workers }\end{array}$ & $7,7 \%$ & $16,0 \%$ & $7,1 \%$ & $15,5 \%$ \\
\hline $\begin{array}{c}\text { Skilled agricultural and fishery } \\
\text { workers }\end{array}$ & $57,6 \%$ & $0,0 \%$ & $63,0 \%$ & $0,0 \%$ \\
\hline Craft and related trades workers & $9,6 \%$ & $15,4 \%$ & $9,0 \%$ & $12,4 \%$ \\
\hline $\begin{array}{c}\text { Plant and machine operators } \\
\text { and assemblers }\end{array}$ & $4,3 \%$ & $7,1 \%$ & $3,2 \%$ & $7,0 \%$ \\
\hline $\begin{array}{c}\text { Agricultural, fishery and related } \\
\text { labourers }\end{array}$ & $2,3 \%$ & $0,0 \%$ & $2,2 \%$ & $0,0 \%$ \\
\hline Rest elementary occupations & $4,5 \%$ & $7,7 \%$ & $3,4 \%$ & $7,0 \%$ \\
\hline Total & 874138 & 3560393 & 623040 & 3020421 \\
\hline
\end{tabular}

Source: Own estimations using Eurostat's EU-SILC microdata.

We note that, before the crisis, over $40 \%$ of the labour force of agricultural population worked in non-agricultural occupations. This percentage decreases significantly in the first two years of the crisis. This is the result of the loss of non-agricultural jobs by members of agricultural households and of the withdrawal from agricultural population of individuals who had a connection with other professions. Both these phenomena contribute to a more intensive dissociation of the agricultural population from the rest of the country's population. This does not mean total separation, as it is evident from table 7 that one-third of residents continues to be associated with non-agricultural activity.

Finally, regarding working time, we observe a significantly greater working time of the agricultural population. This is mainly the result of the existence of a large proportion of selfemployed workers, who generally work more hours than wage-labourers, but without taking labour intensity into account.

Table 8 - Working time of agricultural population, 2009, 2011

\begin{tabular}{|c|c|c|c|c|}
\hline \multirow{2}{*}{$\mathrm{n} / \mathrm{n}$} & \multicolumn{2}{|c|}{2009} & \multicolumn{2}{c|}{2011} \\
\cline { 2 - 5 } & $\begin{array}{c}\text { Agricultural } \\
\text { population }\end{array}$ & $\begin{array}{c}\text { Non agricultural } \\
\text { population }\end{array}$ & $\begin{array}{c}\text { Agricultural } \\
\text { population }\end{array}$ & $\begin{array}{c}\text { Non agricultural } \\
\text { population }\end{array}$ \\
\hline Working time & 43,73 & 40,24 & 42,15 & 39,84 \\
\hline
\end{tabular}

Source: Own estimations using Eurostat's EU-SILC microdata. 
All the above are the key demographic and professional characteristics of the Greek population emerging from the preceding analysis. We now proceed to the study of living conditions and poverty of the agricultural population, always in comparison with the rest of the country's population.

\section{POVERTY OF AGRICULTURAL POPULATION}

Based on the precedent definition of poverty and the identification of agricultural population, we will proceed to the study of living conditions and poverty of this population in Greece. This analysis is performed for the first time with this methodology. In table 9 we present the poverty rates and the contribution to poverty of the agricultural, non-agricultural and total population of Greece.

Table 9 - Poverty rate and contribution to poverty of agricultural population, 2009-2011

\begin{tabular}{|c|c|c|c|c|c|c|}
\hline \multirow{2}{*}{$\mathrm{n} / \mathrm{n}$} & \multicolumn{2}{|c|}{2009 (incomes 2008) } & \multicolumn{2}{|c|}{2010 (incomes 2009) } & \multicolumn{2}{|c|}{2011 (incomes 2010) } \\
\cline { 2 - 7 } & $\begin{array}{c}\text { Poverty rate } \\
(\%)\end{array}$ & $\begin{array}{c}\text { Contribution to } \\
\text { poverty }\end{array}$ & $\begin{array}{c}\text { Poverty rate } \\
(\%)\end{array}$ & $\begin{array}{c}\text { Contribution to } \\
\text { poverty }\end{array}$ & $\begin{array}{c}\text { Poverty rate } \\
(\%)\end{array}$ & $\begin{array}{c}\text { Contribution to } \\
\text { poverty }\end{array}$ \\
\hline $\begin{array}{c}\text { Agricultural } \\
\text { population }\end{array}$ & 32,7 & $34,3 \%$ & 33,0 & $32,2 \%$ & 33,3 & $27,8 \%$ \\
\hline $\begin{array}{c}\text { Non agricultural } \\
\text { population }\end{array}$ & 16,3 & $65,7 \%$ & 17,0 & $67,8 \%$ & 18,8 & $72,2 \%$ \\
\hline Total & 19,7 & $100,0 \%$ & 20,1 & $100,0 \%$ & 21,4 & $100,0 \%$ \\
\hline
\end{tabular}

Source: Own estimations using Eurostat's EU-SILC microdata.

Before the crisis, the agricultural population had twice the poverty rate of the rest of the population. During the first two years of crisis, the poverty risk of farmers rises slightly, while that of the rest of the population is increasing at a faster rate, slightly reducing the difference between them. However, it remains rocketing, placing the members of agricultural households among the poorest people in Greece. This finding is very important as it describes in the most absolute way the living conditions of agricultural households. It occurs, of course, on the basis of the income declared in the survey and it may also be argued that life in the countryside is less extravagant and has smaller financial demands. However, the wide divergence of proportion compared to the rest of the population does not leave much room for misinterpretation. Indeed, a large part of agricultural households are experiencing conditions of intense poverty.

Table 10 - Poverty rate before and after transfers, 2009-2011

\begin{tabular}{|c|c|c|c|c|c|c|c|c|c|c|}
\hline \multirow{2}{*}{$\mathrm{n} / \mathrm{n}$} & \multicolumn{3}{|c|}{2009 (incomes 2008) } & \multicolumn{3}{c|}{2010 (incomes 2009) } & \multicolumn{3}{c|}{2011 (incomes 2010) } \\
\cline { 2 - 10 } & $\begin{array}{c}\text { Agricultural } \\
\text { population }\end{array}$ & $\begin{array}{c}\text { Non } \\
\text { agricultural } \\
\text { population }\end{array}$ & Total & $\begin{array}{c}\text { Agricultural } \\
\text { population }\end{array}$ & $\begin{array}{c}\text { Non } \\
\text { agricultural } \\
\text { population }\end{array}$ & Total & $\begin{array}{c}\text { Agricultural } \\
\text { population }\end{array}$ & $\begin{array}{c}\text { Non } \\
\text { agricultural } \\
\text { population }\end{array}$ & Total \\
\hline $\begin{array}{c}\text { After } \\
\text { social } \\
\text { transfers }\end{array}$ & 32,7 & 16,3 & 19,7 & 33,0 & 17,0 & 20,1 & 33,3 & 18,8 & 21,4 \\
\hline $\begin{array}{c}\text { Before } \\
\text { pensions } \\
\text { and other } \\
\text { social } \\
\text { transfers }\end{array}$ & 64,4 & 36,1 & 42,0 & 65,1 & 37,4 & 42,8 & 66,0 & 40,4 & 44,9 \\
\hline $\begin{array}{c}\text { Before } \\
\text { other } \\
\text { social } \\
\text { transfers }\end{array}$ & 60,6 & 33,9 & 39,5 & 61,9 & 34,4 & 39,8 & 61,8 & 37,9 & 42,1 \\
\hline $\begin{array}{c}\text { Before } \\
\text { pensions }\end{array}$ & 37,2 & 18,9 & 22,7 & 38,7 & 20,2 & 238 & 39,0 & 21,7 & 24,8 \\
\hline
\end{tabular}

Source: Own estimations using Eurostat's EU-SILC microdata. 
As shown in table 10 , this poverty would have taken tremendous dimensions $166 \%$ in 2011) if not for old age and survival benefits and other social transfers in cash for these households. However, we see a slightly lower incidence of all transfers in reducing poverty in the agricultural population compared with the rest of the population and this raises a question on the efficiency of the distribution of such transfers.

In regard to gender, which is an important aspect of this research, we observe a significant deviation of poverty rate for women compared to that of men of the agricultural population, a divergence that is not observed in the rest of the population. This difference is reduced during the two years of the crisis but is still immanent. The difference will be better explained subsequently with the study of the conditions of employment of the agricultural population.

Table 11 - Poverty rate according to sex, 2009, 2011

\begin{tabular}{|c|c|c|c|c|}
\hline \multirow{3}{*}{$n / n$} & \multicolumn{2}{|c|}{2009} & \multicolumn{2}{|c|}{2011} \\
\hline & $\begin{array}{l}\text { Agricultural } \\
\text { population }\end{array}$ & $\begin{array}{c}\text { Non agricultural } \\
\text { population }\end{array}$ & $\begin{array}{l}\text { Agricultural } \\
\text { population }\end{array}$ & $\begin{array}{c}\text { Non agricultural } \\
\text { population }\end{array}$ \\
\hline & \multicolumn{4}{|c|}{ Poverty rate $(\%)$} \\
\hline Males & 29 & 16 & 32 & 18 \\
\hline Females & 36 & 16 & 35 & 19 \\
\hline
\end{tabular}

Source: Own estimations using Eurostat's EU-SILC microdata.

As for employment status, employees working full-time present the lowest poverty rate among the agricultural population. Since only a very small part of those actually works in the agricultural sector, it can safely be argued that members of farming families who have non agricultural occupations have managed to improve their income and living conditions. Therefore, employment outside agricultural occupations is a source of economic relief for the agricultural population.

Unlike employees, the category of self-employed without employees constitutes the basic type of Greek farmer, who is the owner and the worker of the land, mainly in the form of family business. They have a double poverty risk than that of wage-labourers and the same with pensioners. Even more, the difference between employees and self-employedpensioners increases because of the crisis. Namely, those of the agricultural population that kept their wage employment have seen their situation improving, compared to others. ${ }^{5}$ However, as we have seen, a large part of the agricultural population's employees have lost their jobs. This ranked them in the category of the unemployed of the agricultural population, who saw their poverty rate reach $50 \%$ within two years, while before the crisis they had a poverty rate similar to the self-employed. This is an important diversification for the agricultural population, in which, while pre-crisis poverty was shared more equally among the working and the non working individuals, with the arrival of the crisis the unemployed bear more weight. This probably is due to the fact that most of them were wage-labourers. As a conclusion it can be established that, while the employed in agriculture show a high percentage of poverty in relation to wage-labourers, however they are not under the risk of moving to much larger poverty rates via unemployment.

The poverty rates for pupils and students of the agricultural population are especially high (much greater than those of others), showing the great economic deterioration in agricultural family that derives by the existence of people who are not working.

Interesting conclusions arise from the examination of the situation of employment in terms of gender (table 13). We observe that women wage laborers of the agricultural population have a significantly lower poverty rate than men, as in the rest of the population. The most possible explanation is that they usually are the second earner in a household and

\footnotetext{
${ }^{5}$ It should be noted the way in which poverty is measured in this survey represents a relative size. This means that it occurs compared to the total population. Thus, it is possible that the incomes and the living standards of a population group deteriorate, but the poverty rate in this group is reduced, if the incomes of the remaining population have declined even more. So, the reduction of poverty rates in particular groups of the Greek population does not necessarily imply that they improved their living standards, which is very likely to have deteriorated due to the overall reduction in income. It means that they have improved their relevant, compared to the rest of the population, living standard.
} 
the fact that they have a salaried position improves the situation of the household. Conversely, if the man is a wage-labourer the results are not so strong, because he may be the only employee of the household. Without doubt, this difference is almost annihilated by the crisis, meaning that female and male wage-labourers who managed to keep their jobs have almost equalized their financial benefits.

It is also interesting that there is a very small poverty rate among self-employed women with staff, as in the rest of the population, a phenomenon that shares the same explanation as for the employed women given previously.

Table 12 - Poverty rate according to employment status, 2009, 2011

\begin{tabular}{|c|c|c|c|c|c|c|c|c|}
\hline \multirow{3}{*}{$\begin{array}{c}\mathrm{n} / \mathrm{n} \\
\begin{array}{c}\text { Employment } \\
\text { status }\end{array}\end{array}$} & \multicolumn{4}{|c|}{2009} & \multicolumn{4}{|c|}{2011} \\
\hline & \multicolumn{2}{|c|}{ Agricultural population } & \multicolumn{2}{|c|}{$\begin{array}{c}\text { Non agricultural } \\
\text { population }\end{array}$} & \multicolumn{2}{|c|}{ Agricultural population } & \multicolumn{2}{|c|}{$\begin{array}{c}\text { Non agricultural } \\
\text { population }\end{array}$} \\
\hline & $\begin{array}{l}\text { Poverty } \\
\text { rate } \\
(\%)\end{array}$ & $\begin{array}{c}\text { Contribution } \\
\text { to poverty }\end{array}$ & $\begin{array}{l}\text { Poverty } \\
\text { rate } \\
(\%)\end{array}$ & $\begin{array}{l}\text { Contribution } \\
\text { to poverty }\end{array}$ & $\begin{array}{l}\text { Poverty } \\
\text { rate } \\
(\%)\end{array}$ & $\begin{array}{c}\text { Contribution } \\
\text { to poverty }\end{array}$ & $\begin{array}{l}\text { Poverty } \\
\text { rate } \\
(\%)\end{array}$ & $\begin{array}{l}\text { Contribution } \\
\text { to poverty }\end{array}$ \\
\hline $\begin{array}{l}\text { Employee - } \\
\text { Full time }\end{array}$ & 15 & $6,4 \%$ & 7 & $15,8 \%$ & 13 & $3,4 \%$ & 6 & $8,9 \%$ \\
\hline $\begin{array}{l}\text { Employee - } \\
\text { Part time }\end{array}$ & 37 & $1,7 \%$ & 21 & $3,5 \%$ & 31 & $1,0 \%$ & 19 & $3,1 \%$ \\
\hline $\begin{array}{c}\text { Self } \\
\text { employed } \\
\text { without } \\
\text { employees }\end{array}$ & 31 & $22,6 \%$ & 23 & $11,0 \%$ & 33 & $20,2 \%$ & 17 & $6,3 \%$ \\
\hline $\begin{array}{c}\text { Self } \\
\text { employed } \\
\text { with } \\
\text { employees }\end{array}$ & 28 & $2,6 \%$ & 12 & $2,7 \%$ & 26 & $1,7 \%$ & 10 & $1,4 \%$ \\
\hline $\begin{array}{c}\text { Self } \\
\text { employed - } \\
\text { Part time }\end{array}$ & 41 & $4,9 \%$ & 27 & $2,1 \%$ & 29 & $3,3 \%$ & .31 & $1,6 \%$ \\
\hline Unemployed & 34 & $4,1 \%$ & 32 & $12,2 \%$ & 48 & $13,4 \%$ & 34 & $26,7 \%$ \\
\hline $\begin{array}{l}\text { Pupil, } \\
\text { student }\end{array}$ & 48 & $5,5 \%$ & 20 & $10,8 \%$ & 34 & $3,6 \%$ & 24 & $10,9 \%$ \\
\hline In retirement & 31 & $37,9 \%$ & 11 & $13,2 \%$ & 30 & $38,5 \%$ & 14 & $16,5 \%$ \\
\hline $\begin{array}{l}\text { Domestic } \\
\text { tasks }\end{array}$ & 41 & $9,7 \%$ & 26 & $24,1 \%$ & 53 & $11,1 \%$ & 29 & $22,1 \%$ \\
\hline $\begin{array}{c}\text { Other } \\
\text { inactive }\end{array}$ & 40 & $4,6 \%$ & 28 & $4,6 \%$ & 39 & $3,8 \%$ & 24 & $2,5 \%$ \\
\hline
\end{tabular}

Source: Own estimations using Eurostat's EU-SILC microdata.

Table 13 - Poverty rate according to employment status and gender, 2009, 2011

\begin{tabular}{|c|c|c|c|c|c|c|c|c|}
\hline & \multicolumn{4}{|c|}{2009} & \multicolumn{4}{|c|}{2011} \\
\hline & \multicolumn{2}{|c|}{$\begin{array}{l}\text { Agricultural } \\
\text { population }\end{array}$} & \multicolumn{2}{|c|}{$\begin{array}{c}\text { Non agricultural } \\
\text { population }\end{array}$} & \multicolumn{2}{|c|}{$\begin{array}{l}\text { Agricultural } \\
\text { population }\end{array}$} & \multicolumn{2}{|c|}{$\begin{array}{c}\text { Non agricultural } \\
\text { population }\end{array}$} \\
\hline & Males & Females & Males & Females & Males & Females & Males & Females \\
\hline Employment status & \multicolumn{8}{|c|}{ Poverty rate (\%) } \\
\hline Employee - Full time & 17 & 11 & 10 & 04 & 13 & 11 & 6 & 5 \\
\hline Employee - Part time & 32 & 39 & 26 & 19 & 31 & 31 & 32 & 14 \\
\hline $\begin{array}{c}\text { Self employed } \\
\text { without employees }\end{array}$ & 32 & 31 & 27 & 16 & 34 & 32 & 16 & 17 \\
\hline $\begin{array}{l}\text { Self employed with } \\
\text { employees }\end{array}$ & 35 & 4 & 14 & 3 & 32 & 5 & 11 & 9 \\
\hline $\begin{array}{l}\text { Self employed - Part } \\
\text { time }\end{array}$ & 34 & 44 & 24 & 28 & 35 & 27 & 40 & 26 \\
\hline Unemployed & 24 & 45 & 28 & 35 & 52 & 43 & 39 & 29 \\
\hline Pupil, student & 41 & 54 & 21 & 18 & 36 & 33 & 23 & 25 \\
\hline In retirement & 29 & 32 & 13 & 09 & 28 & 31 & 17 & 11 \\
\hline Domestic tasks & & 41 & & 26 & & 53 & & 29 \\
\hline Other inactive & 37 & 43 & 29 & 26 & 40 & 37 & 26 & 22 \\
\hline
\end{tabular}

Source: Own estimations using Eurostat's EU-SILC microdata. 
There is also a large difference in poverty rate between men and women among the unemployed, where, before the crisis, women of the agricultural population had nearly twice the poverty rate compared to men. This image is reversed within two years and in 2011 unemployed men have a significantly higher poverty rate than women, indicating that the large increase in unemployment affected more male than female people. Finally, the fulfilment of domestic tasks and care responsibilities that is prerogative of women both in agriculture and in the rest of the population has very high rates of poverty, rising significantly by the crisis. This fact highlights the financial hardship of the families of the agricultural population that we have been able to obtain income from a second person.

\section{CONCLUSION}

This analysis of basic demographic and employment characteristics and living conditions of the agricultural population is the first of its kind in Greece that uses this particular method and the statistical data of the EU-SILC survey. It provides a detailed image of the agricultural population before and at the beginning of the economic crisis.

The agricultural population, in the way it was defined in this research, constituted, before the crisis, over $20 \%$ of the Greek population. An important part however had and still has an income outside of the agricultural sector, but it is connected whatsoever with the cultivation of land, which has strong family characteristics in Greece and thus implicates all members of agricultural households. The onset of the crisis led to a rapid decrease in the agricultural population. This decrease has mostly influenced the younger and more productive ages, reinforcing even more the pronounced aging occurring within it.

Regarding labour characteristics, the majority of the population consists of pensioners, an expected result of the aging agricultural population. The vast majority of land farmers are self-employed, farmers of their own land, while the share of farm wage-labourers is very small. However, a large part of the economically active agricultural population, which was around $40 \%$ before the crisis, engages in activities outside agriculture, usually in the form of wage labour. The crisis has affected this portion the most, decreasing the alternative employments of the agricultural population and increasing the share of agricultural occupations. At the same time, it led to a significant increase in unemployment, which until then was not a major problem. The position of women towards employment is more equal to that of men compared with the rest of the population, since there is a significantly smaller percentage of household work. Women are more geared toward agriculture through selfemployment and less than men toward other non-agricultural occupations.

The findings of this survey are particularly striking in terms of living conditions and the poverty of the agricultural population. The poverty rate is twice that of the rest of the population. Providing too little consolation is the fact that, during the early years of the crisis, the poverty rate of farm families has increased proportionately less than that of the rest of the country's population, which indicates that the beginning of the crisis did not affect farmers and their families as much.

Poverty before pensions and other social transfers in 2009 would have reached, for farming families, the enormous percentage of $64.4 \%$. This percentage is mainly decreased by pensions, like in the rest of the population, while the impact of other social transfers is small. However, there is a slightly lower effectiveness of pensions on poverty reduction, compared with the rest of the population.

The smallest poverty rate among the agricultural population regards full-time employees, who have mostly non-agricultural occupations. Therefore, employment outside agricultural occupations was and continues to be a source of economic relief for the agricultural population. The crisis however reduced the part of the agricultural population that is employed outside agriculture, worsening living conditions and separating it, in terms of employment, more than the rest of the population of the country.

The position of women is worse in terms of poverty than that of men, which is not true for the rest of the population, although the crisis has reduced the difference. The 
phenomenon of exclusively domestic work (before and after the crisis) and the unemployment of women (before the crisis) have an important role in this.

This is an initial overview of the basic features of the agricultural population in Greece. It is an aged population with many retirees and little involvement of the new generation. Those who work in agriculture are self-employed, while a large part of the population has spread into non-agricultural activities, mainly through wage labour, a tendency partially reversed by the crisis. The status of women although it is more equal in terms of labour (less domestic work), it is worse in terms of income (higher percentage of poverty). The poverty rates found in the agricultural population are impressive and could be described as horrific. On average poverty rates are twice as much as the rest of the population and the early years of the crisis barely changed this image. The employees that work outside the agricultural sector are in better shape in terms of poverty, something that reveals and justifies the escapism of the agricultural population. The onset of the crisis led to a rapid decrease in the agricultural population, accelerating the long term tendency. It also further improved (relative, of course) the position of wage-labourers, but rapidly worsened the position (in terms of poverty) of the unemployed coming from their ranks. In contrast, despite the crisis, selfemployed farmers have maintained their living standard, which was not particularly high anyway.

The study of employment and living conditions as well as poverty of the agricultural population of Greece has revealed, to a large extent, the characteristics of this population, along with its historically significant economic, social and political importance for Greece. This investigation should be extended to the following years of crisis and we hope that it contributes positively to addressing some of the problems that this population faces.

\section{REFERENCES}

1. Atkinson, A.B. (1983). The Economics of Inequality, Sec. Ed., Oxford: Clarendon Press.

2. Atkinson,A.B., Rainwater,L. \& Smeeding,T., (1995). Income Distribution in European Countries. Cambridge Working Papers in Economics, 9535, Faculty of Economics, University of Cambridge.

3. Daoutopoulos G., Kazakopoulos L., Kousi M. (2005). Agricultural Sociology. 3rd edition, Thessaloniki: Zygos (In Greek).

4. Esping Andersen, G. (1990). The Three Worlds of Welfare Capitalism. Oxford: Policy Press.

5. Eurostat (1995). Manual of the Total Income of Agricultural Households. (Rev.1), Theme 5 Series E. Luxembourg: Eurostat.

6. Central Statistics Office (2008)., Income of agricultural households in Ireland. Dublin: Stationery Office.

7. Chossudovsky, M. (1998). World poverty at the end of the 20th century. In: Petmezidou M., Papatheodorou C. (eds) Poverty and Social Exclusion, Athens: Exantas (in Greek).

8. FAO (2010), Data Structure, Concepts and Definitions common to FAOSTAT and CountrySTAT framework.

9. Ferrera, M. (1996). The Southern Model of Welfare in Social Europe. Journal of European Social Policy, 6, pp. 17-37.

10. Hagenaars, A.J.M., De Vos, K. and Zaidi, A. (1994). Poverty Statistics in the Late 1980s: Research Based on Micro-Data. Luxembourg: Office for Official Publications of the European Communities.

11. Leibfreid, S. (1992). Towards a European Welfare State? On Integrating Poverty Regimes into the European Community. In Ferge, Z. and Kolberg, J.E. (eds.), Social Policy in a Changing Europe. Frankfurt am Main: European Centre for Social Welfare Policy and research.

12. OECD (1984). Handbook of Household Surveys. Revised Edition, Studies in Methods, Series F, No. 31, New York: United Nations.

13. OECD (1993). What Future for Our Countryside? Paris: OECD Publishing. 
14. OECD (2006). Rural Policy Reviews, the New Rural Paradigm, Policies and Governance. Paris: OECD Publishing.

15. Papatheodorou, C. (2000). Decomposing Inequality by Population Subgroups in Greece: Results and Policy Implications. Distributional Analysis Research Programme No. DARP 49, LSE-STICERD. London: London School of Economics and Political Science.

16. Papatheodorou, C. (2008). The public dialogue for poverty in Greece and the legitimization of dominant national and international policies, In Aggelidis, M., Sakkas D., Gravaris D. (eds.) Social Theory and Political Responsibility. Athens: Gutenberg (in Greek).

17. Papatheodorou C. and Petmezidou M. (2004). Inequality, poverty and redistribution through social transfers: Greece in a comparative perspective. In: Petmezidou M., Papatheodorou C. (eds) Poverty and Social Exclusion, Athens: Exantas (in Greek).

18. Papatheodorou C., Dafermos, G., Danchev, S and Marselou, A. (2008). Economic Inequality and Poverty in Greece: Comparative Analysis and Intertemporal Trends. Scientific reports 1. Athens: Observatory of Poverty, inequality, incomes ans social exclusion, INE GSEE (in Greek).

19. Petmesidou, M. (1996). Social protection in Southern Europe: Trends and Prospects. Journal of Area Studies, 9, pp. 95-125.

20. Townsend, P. (2004). For a reform of international social policy against poverty. In: Petmezidou M., Papatheodorou C. (eds) Poverty and Social Exclusion, Athens: Exantas (in Greek). 